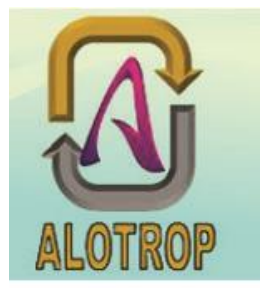

\section{PENERAPAN MODEL DISCOVERY LEARNING DENGAN MENGGUNAKAN MEDIA VIDEO UNTUK MENINGKATKAN AKTIVITAS BELAJAR DAN HASIL BELAJAR SISWA KELAS XI IPA 1 SMAN 1 KOTA BENGKULU} Sitti Utami Medianty ${ }^{1}$, Amrul Bahar $^{2}$, Elvinawati ${ }^{3}$ 1,2,3 Program Studi Pendidikan Kimia Jurusan PMIPA FKIP Universitas Bengkulu

email :sittiutami16mei1994@gmail.com

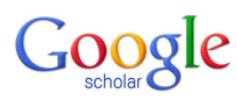

\section{MENDELEY Oonesearch PKP|INDEX}

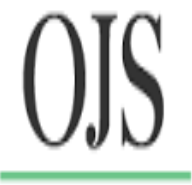

Open Journal Systems

\title{
Abstract
}

\begin{abstract}
[APPLICATION OF DISCOVERY LEARNING MODEL BY USING VIDEO MEDIA TO INCREASE LEARNING ACTIVITIES AND STUDENT LEARNING RESULT CLASS XI IPA 1 SMAN 1 BENGKULU CITY]. The research has goals to improve the activity and learning outcomes chemistry at XI IPA 1 class in SMA Negeri 1 Bengkulu that consist of 30 students: 23 girls and 7 boys. This study is research of class action on thermochemistry subjects by discovery learning model. This research consist three cycle on four stage: planning, action, absorption, and reflection. The data collected using test and non test that consist of post test and observation sheet of activity teacher and student. The data processed using quantitative simple analysis techniques: average score of observation sheet of activity teacher and student, average score, absorption percentage clasical, andclasssical learning completness percentage. From the reseult, we can conculded that chemistry learning process applying discovery learning model using video can improve activity and outcomes learning chemistry student. It can be see from the average score of students. In the first cycle is 69.33 in which the percentage of classical absorption is 86.67 and classical learning completeness is 66.67. The average score of the second cycle is 71,33 in which the percentage of classical absorption is 89.17 and classical learning completeness is 73.33 . The students' average score of the third cycle is 81.33 in which the percentage of classical absorption is 90.37 and classical learning completeness is 86.67 . The teacher's activities of the learning process in the first cycle get average score 26.5 and it is good category, the second cycle is 27.5 and it is good category, the third cycle is 30 and it is good category too. Meanwhile, the student's activities in the first cycle get average score 22.5 and it is good category, the second cycle is 25 and it is a good category, the third cycle is 27 and it is good category.
\end{abstract}

Keywords : Discovery Learning Model Learning, Video Media, Learning Results.

\section{Abstrak}

Penelitian ini merupakan penelitian tindakan kelas penerapan model pembelajaran Discovery Learning menggunakan media video pada pokok bahasan termokimia dalam tiga siklus dengan empat tahapan yaitu perencanaan, pelaksanaan tindakan, observasi dan refleksi pada setiap siklus yang bertujuan untuk meningkatkan aktivitas dan hasil belajar kimia siswa kelas XI IPA 1 SMA N 01 Kota Bengkulu tahun ajaran 2016/2017.Subjek penelitian berjumlah 30 siswa, yang terdiri atas 23 perempuan dan 7 laki-laki. Data diperoleh menggunakan post test dan lembar observasi aktivitas guru dan siswa, yang diolah menggunakan teknik analisa kuantitatif sederhana yaitu nilai rata-rata skor lembar observasi ,persentase daya serap klasikal dan ketuntasan belajar klasikal. Dari hasil penelitian dapat disimpulkan bahwa penerapan model pembelajaran Discovery Learning menggunakan media video terbukti mampu meningkatkan aktivitas dan hasilbelajar kimia siswa. Pada siklus I diperoleh skor rata-rata aktivitas guru 26,5 (kategori baik), aktivitas siswa 22,5 (kategori cukup), nilai rata-rata siswa71,33,persentase daya serap klasikal 86,67\% dan ketuntasan belajar klasikal 66,67\%. .Padas iklus II diperoleh skor rata-rata untuk aktivitas guru 27,5 (kategori baik), aktivitas siswa 25 (kategori baik) dengan nilai rata-rata siswa 73,33, persentase daya serap klasikal 89,17\% dan ketuntasan belajar klasikal 73,33\% . Pada siklus III diperoleh skor rata-rata aktivitas guru 30 (kategori baik), aktivitas siswa 27 (kategori baik ), nilai ratarata siswa 81,33 , persentase daya serap klasikal 90,37 \% dan ketuntasan belajar klasikal 86,67\%.

Kata kunci : Model Pembelajaran Discovery Learning, Media Video, Hasil Belajar.

\section{PENDAHULUAN}

Tujuan pendidikan nasional Indonesia saat ini diuraikan di dalam Undang-undang Sistem Pendidikan Nasional Nomor 20 Tahun 2003 [1]. Untuk mencapai tujuan pendidikan tersebut, maka diperlukan kurikulum pendidikan sebagai wadah yang akan menentukan arah pendidikan [2]. Karena itu seiring dengan perkembangan zaman, maka kurikulum juga terus berkembang [3], yang dilakukan atas beberapa pertimbangan dalam upaya untuk menyesuaikan diri dengan tuntutan zaman [4]. Kurikulum 2013 yang berlaku saat ini merupakan rangkaian penyempurnaan terhadap kuriku- 
lum sebelumnya [5], yang lebih menekankan pada kompetensi berbasis sikap, keterampilan dan pengetahuan [6], dengan pembelajaran yang menggunakan pendekatan scientifik dan tematikintegratif [7], serta memadukan antara kemampuan sikap, keterampilan dan pengetahuan [8], sehingga dalam pembelajaran dikelas hasil belajar siswa haruslah juga mencakup ketiga kemampuan tersebut [9]. Berkaitan dengan kurikulum 2013, ilmu kimia yang diajarkan di SMA merupakan suatu ilmu yang diperoleh dan dikembangkan berdasarkan eksperimen yang mencari jawaban yang berkaitan dengan gejala alam [10], sehingga perlu selalu untuk melibatkan keterampilan dan penalaran [11]. Hasil dari observasi awal di SMAN 1 Kota Bengkulu tahun ajaran 2016/2017 pada kelas XI IPA 1 terindentifikasi terjadi beberapa masalah dalam pelaksanaan pembelajaran di kelas antara lain berupa proses pembelajaran yang didominasi guru dengan metode ceramah, jarang sekali melakukan praktikum, siswa kurang aktif, pelajaran kimia sulit dipahami serta membosankan dan masih rendahnya nilai rata-rata ujian harian pada beberapa topik, dimana beberapa upaya yang sudah dilakukan guru belum menunjukkan perubahan yang berarti. Dari berbagai model pembelajaran yang sesuai dengan karakteristik pembelajaran kimia sesuai yang diharapkan pada kurikulum 2013 adalah menggunakan model penemuan yaitu dengan discovery learning $(D L)$, agar siswa dapat menguasai materi dengan baik [12]. Model $D L$ dapat disempurnakan dengan menggunakan bantuan media video [13], untuk memanfaatkan kemampuan media video dalam peningkatan setiap ranah baik kognitif, afektif, maupun psikomotorik [14] yang akan memperkuat pemahaman siswa terhadap materi ajar [15].

Tujuan dari dilakukannya penelitian ini adalah menerapkan model Discovery Learning $(D L)$ dengan menggunakan media video dalam usaha untuk meningkatkan aktivitas belajar dan hasil belajar siswa kelas XI IPA 1 SMAN 1 Kota Bengkulu.

\section{METODE PENELITIAN}

Jenis penelitian yang digunakan pada penelitian ini adalah penelitian tindakan kelas (PTK), yang merupakan suatu pencermatan terhadap kegiatan belajar berupa sebuah tindakan, yang sengaja dimunculkan dan terjadi dalam sebuah kelas secara bersama [16]. Tindakan tersebut diberikan oleh guru atau dengan arahan dari guru yang dilakukan oleh siswa [17]. Subyek penelitian adalah siswa kelas XI IPA 1 SMA Negeri 1 Kota Bengkulu tahun ajaran 2016/2017. Penelitian Tindakan Kelas (PTK) akan dilaksanakan menggunakan model Discovery Learning $(D L)$ dalam 3 siklus, masing-masing selama 2 kali 45 menit pelajaran untuk setiap pokok bahasan yaitu pokok bahasan sistem dan lingkungan (siklus 1), reaksi eksoterm (siklus 2) dan reaksi endoterm (siklus3). PTK dilaksanakan dengan empat tahap untuk setiap siklusnya, yaitu tahap perencanaan tindakan (planning), tahap pelaksanaan tindakan (action), tahap pengamatan atau observasi (observation) dan tahap refleksi (reflection) [18].

Dalam penelitian ini instrumen penelitian yang digunakan adalah berupa tes hasil belajar pada akhir siklus, lembar observasi aktivitas guru dan siswa, lembar penilaian keterampilan dan lembar diskusi siswa. Instrumen tes merupakan alat atau prosedur yangdigunakan untuk mengetahui atau mengukur sesuatu dalam suasana, dengan cara dan aturan yang telah ditentukan [19]. Tes pada akhir siklus bertujuan untuk mengetahui penguasaan materi pembelajaran oleh siswa serta mengukur besarnya peningkatan hasil belajar siswa [20]. Hasil belajar merupakan hasil dari suatu interaksi tindakbelajar siswa dan tindak mengajar guru [21], sehingga hasil belajar adalah suatu pencapaian tujuan pengajaran guru dan merupakan peningkatan kemampuan mental siswa [22]. Pada penelitian ini hasil belajar yang dinilai adalah pada aspek kognitif (pengetahuan) berupa angka yang diperoleh melalui tes yang diberiakan pada akhir pembelajaranberbentuk soal soal uraian (essay), yang dilengkapi kunci jawaban dan pedoman penskoran serta disusun berdasarkan indikator pencapaian kompetensi.Pada penelitian ini, observasi dilakukan menggunakan instrumen observasi untuk mengamati aktivitas guru dan siswa sebagai pedoman keberhasilan proses pembelajaran dalam satu siklus untuk dijadikan bahan refleksi untuk siklus selanjutnya. Instrumen observasi adalah suatu proses pengamatan dan pencatatan secara sistematis, logis, objektif, dan rasional mengenai berbagai fenomena, baik dalam situasi yang sebenarnya maupun dalam situasi buatan untuk mencapai tujuan tertentu [23]. Hal ini dilakukan untuk mengetahui kekurangan yang dilakukan guru pada saat mengajar, mengamati aktivitas guru pada langkah -langkah pembelajaran 
inkuiri terbimbing saat menyajikan pertanyaan atau masalah, membuat hipotesis, merancang percobaan, melakukan percobaan untuk memperoleh informasi, mengumpulkan dan menganalisis data serta membuat kesimpulan \{24].Lembar observasi aktivitas siswa, digunakan untuk mengetahui sejauh mana keaktifan dan keikutsertaan siswa dalam mengikuti proses belajar dengan menggunakan model discovery learning [25]. Pada penelitian ini untuk memperkuat hasil penelitian akan dilengkapi dengan pengumpulan dokumen yang berfungsi untuk menghimpun secara selektif bahan-bahan yang dipergunakan didalam kerangka atau landasan teori, berupa foto-foto kegiatan belajar, dan nilai kimia siswa pada materi Termokimia di kelas XI IPA 1 SMA N 1 Kota Bengkulu.

Adapun alur penelitian tindakan kelas pada penelitian ini dapat dilihat pada Gambar 1.

\begin{tabular}{|c|c|}
\hline Siklus 1 & $\begin{array}{c}\text { Kegiatan model pembelajaran } \\
\text { Discovery Learning }\end{array}$ \\
\hline $\begin{array}{l}\text { Perencanaan } \\
\text { (Planning) }\end{array}$ & $\begin{array}{l}\text { 1. Mempersiapkanperangkatpembela } \\
\text { jaranseperti :RPP dan skenario } \\
\text { pembelajaran untuksetiapsiklus. } \\
\text { 2. Membuatlembarobservasiaktivitas } \\
\text { guru aktivitassiswa. } \\
\text { 3. Mempersiapkan media video. } \\
\text { 4. MembuatLDS } \\
\text { 5. Membuatkelompok5 } \\
\text { siswa/kelompok. } \\
\text { 6. Menyiapkan alat dan bahan } \\
\text { pembelajaran } \\
\text { 7. Membuat soal tes. } \\
\text { 8. Membuat jawaban soal tes }\end{array}$ \\
\hline $\begin{array}{l}\text { Pelaksanan } \\
\text { tindakan } \\
\text { (action) }\end{array}$ & $\begin{array}{l}\text { 1. Pelaksanaan pembelajaran sesuai } \\
\text { dengan RPP. } \\
\text { 2. Melakukan pembahasan } \\
\text { 3. Siswa mengambil kesimpulan } \\
\text { 4. Mengadakan evaluasi. }\end{array}$ \\
\hline $\begin{array}{l}\text { Observasi } \\
\text { (observation) }\end{array}$ & $\begin{array}{l}\text { Observasi terhadap aktivitas guru dan } \\
\text { siswa. }\end{array}$ \\
\hline $\begin{array}{l}\text { Refleksi } \\
\text { (reflection) }\end{array}$ & $\begin{array}{l}\text { Hasil dari refleksi sebagai untuk pe- } \\
\text { doman menyusun rencana pada siklus } \\
2 \text {. }\end{array}$ \\
\hline \multicolumn{2}{|r|}{ Siklus 2} \\
\hline \multicolumn{2}{|c|}{$\begin{array}{l}\text { SiklusI dilaksanakan dengan melakukan perbaikan } \\
\text { berdasarkan refleksi siklus I. Hasil yang diperoleh dari } \\
\text { siklus II akan dianalisis dan digunakan untuk meng- } \\
\text { ukur keberhasilan pelaksanaan siklus II. Kelemahan } \\
\text { pada siklus II dipelajari untuk memecahkan tindakan } \\
\text { pada siklus III. }\end{array}$} \\
\hline
\end{tabular}

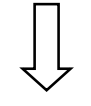

Medianty, S.U., Amrul Bahar, Elvinawati
Siklus 3

Siklus III dilaksanakan dengan melakukan perbaikan berdasarkan refleksi siklus II. Hasil yang diperoleh dari siklus III akan dianalisis dan digunakan untuk melihat sejauh mana penerapan model pembelajaran discovery learning dapat meningkatkan hasil belajar dan aktivitas belajar siswa di kelas XI IPA 1 SMA N 1 Kota Bengkulu.

Gambar 1. Alur Pelaksanaan Penelitian Tindakan Kelas Model Pembelajaran Discovery Learning [26].

Dalam penelitian ini analisis data yang digunakan adalah analisis deskriptif kualitatif, dengan data yang dianalisis ini adalah nilai tes prestasi belajar kimia pada kompetensi dasar termokimia, data pengamatan aktivitas guru dan siswa dalam kegiatan belajar mengajar. Analisis data yang digunakan adalah nilai rata-rata hasil belajar, daya serap klasikal, dan ketuntasan belajar/ ketuntasan klasikal. Daya serap (Ds) akan menunjukkan seberapa banyak siswa yang dapat memahami pelajaran yang telah disampaikan oleh guru. Untuk data hasil observasi akan digunakan untuk merefleksikan siklus yang telah dilakukan dan dianalisis secara deskriptif. Analisis data observasi aktivitas guru dan siswa menggunakan penilaian. Semakin tinggi nilai yang dihasilkan maka akan semakin baik pembelajaran atau sebaliknya. Sebagai indikator keberhasilan pembelajaran adalah berupa aktivitas siswa dan hasil belajar siswa. Tindakan dihentikan setelah siklus III. Kriteria keberhasilan tindakan diterapkan berdasarkan nilai ketuntasan hasil belajar dari sekolah dan pertimbangan penelitian. Kriteria keberhasilan dari tindakan pada penelitian ini adalah daya serap (Ds) meningkat untuk setiap silkusnya (Ds1< Ds2 $<$ Ds3), hasil belajar dari siklus adalah tuntas bila setiap siswanya mendapatkan nilai $\geq 75$ dan tuntas secara klasikal dimana $75 \%$ siswa mendapatkan nilai $\geq 75$ serta aktivitas guru dan siswa yang diamati mengunakan lembar observasi mencapai kategori baik.

\section{HASIL DAN PEMBAHASAN}

Penelitian dilaksanakan pada tanggal 22 Agustus hingga 22 September 2016 di kelas XI IPA 1 SMA N 1 Kota Bengkulu, dengan jumlah siswa 30 orang ( 23 orang wanita dan 7 pria). Hasil observasi awal, diperoleh data nilai rata-rata mata pelajaran kimia pada pokok bahasan termokimia 
adalah 68,93 pada tahun ajaran 2014/2015, yang berarti belum mencapai standar ketuntasan yaitu 75. Pada pelaksanaan pembelajaran siklus I dilakukan dengan menerapkan model pembelajaran Discovery Learning $(D L)$ pada materi Sistem dan Lingkungan. Pelaksanaan tindakan siklus I ini dilaksanakan pada tanggal 26 Agustus 2016. Hasil observasi aktivitas guru diperoleh hasil rata-rata skor dari kedua pengamat adalah 26,5. Hasil ini menunjukkan aktivitas guru dalam melaksanakan pembelajaran dengan model $D L$ untuk siklus I termasuk dalam kategori baik. Hasil rata-rata skor aktivitas siswa pada siklus I diperoleh dari kedua pengamat adalah 22,5, yang menunjukkan aktivitas siswa dalam melaksanakan pembelajaran dengan model $D L$ untuk siklus I termasuk dalam kategori cukup. Hasil analisis data hasil belajar siswa pada siklus I dalam proses pembelajaran dengan penerapan model $D L$ yang sudah dilakukan diperoleh adalah belum mencapai ketuntasan, sehingga perlu dilakukan perbaikan dalam proses pembelajaran pada siklus II.Refleksi pada siklus I ternyata masih banyak kekurangan yang perlu diperbaiki untuk diterapkan pada siklus II.

Pelaksanaan pembelajaran siklus II dilakukan pada materi Reaksi Eksoterm, dengan pelaksanaan tindakan pada tanggal 27 Agustus 2016. Hasil Observasi Aktivitas Guru diperoleh adalah 27,5 yang menunjukkan aktivitas guru dalam melaksanakan pembelajaran dengan model $D L$ termasuk dalam kategori baik. Untuk hasil observasi aktivitas siswadiperoleh adalah 25, yang termasuk dalam kategori baik. Pada siklus II hasil belajar siswa diperoleh belum mencapai ketuntasan, sehingga perlu adanya perbaikan dalam proses pembelajaran pada siklus III. Pada siklus II pelaksanaan proses belajar mengajar pada materi "Reaksi Eksoterm" ternyata masih banyak kekurangan yang perlu diperbaiki untuk diterapkan pada siklus III.

Pelaksanaan pembelajaran siklus III dilaksanakan pada tanggal 02 September 2016. Hasil analisis lembar observasi aktivitas guru pada siklus III yang dilakukan oleh dua pengamat. Berdasarkan hasil rata-rata skor yang diperoleh dari kedua pengamat adalah 30 . Hasil ini menunjukkan aktivitas guru dalam melaksanakan pembelajaran dengan model $D L$ untuk siklus III termasuk dalam kategori baik.

Berdasarkan hasil observasi aktivitas siswa diperoleh hasil rata-rata skor yang diperoleh dari kedua pengamat adalah 27. Hasil ini menunjukkan aktivitas siswa dalam melaksanakan pembelajaran dengan model DLuntuk siklus III termasuk dalam kategori baik.

Pada akhir siklus dilakukan penilaian terhadap proses pembelajaran dengan menerapkan model $D L$, penilaian yang digunakan berupa soal post test. Nilai akhir ini digunakan untuk melihat ketuntasan belajar siswa dan untuk melihat tercapai atau tidaknya ketuntasan belajar secara klasikal. Setelah menganalisa data hasil belajar siswa pada siklus III dalam proses pembelajaran dengan penerapan model $D L$ yang sudah dilakukan diperoleh bahwa secara klasikal proses pembelajaran pada siklus III sudah tuntas, karena ketuntasan belajar secara klasikal apabila $85 \%$ dari jumlah siswa telah mendapat nilai $\geq 75$.

Pelaksanaan proses pembelajaraan siklus III ini merupakan perbaikan dari siklus-siklus sebelumnya. Pada pelaksanaan proses pembelajaran siklus III ini sudah mengalami peningkatan dari siklus-siklus sebelumnya terutama telah tercapainya ketuntasan belajar klasikal dan keaktifan guru dan siswa yang diamati menggunakan lembar observasiaktifitas guru dan siswa.

Adapun hal-hal yang telah dicapai padasiklus III, yaitu : (1) Daya serap klasikal meningkat di setiap siklusnya dimana daya serap siklus II lebih baik dari siklus I dan daya serap siklus III lebih baik dari siklus II (Ds1< Ds2 < Ds3); (2) Hasil belajar telah mencapai ketuntasan belajar sehingga telah tercapai ketuntasan belajar dan $85 \%$ siswa telah memperoleh nilai $\geq 75$, dan (3) Aktivitas guru dan siswa serta hasil belajar siswa berada pada kriteria baik

Penilaian terhadap aktivitas guru saat mengajar dilakukan oleh dua pengamat yaitu dua orang teman sejawat dengan mengisi lembar observasi aktivitas guru yang diberikan. Pada setiap siklusnya, guru banyak melakukan perbaikan dari kekurangan yang terjadi di siklus sebelumnya sehingga terjadi peningkatan terhadap aktivitas guru dalam proses pembelajaran. Guru telah mampu mengelola kegiatan pembelajaran dengan menerapkan model pembelajaran Discovery Learning menggunakan media video dengan baik. Hal ini terlihat dari penilaian observasi guru yang pada siklus I mendapat nilai sebesar 26,5, siklus ke II sebesar 27,5 dan pada siklus III mendapat nilai sebesar 30 sehingga hasil ini menunjukkan aktivitas guru dalam melaksanakan pembelajaran dengan 
model $D L$ untuk siklus III termasuk dalam kategori baik. Aktivitas belajar siswa juga menggunakan lembar observasi yang dinilai oleh dua pengamat pada setiap siklusnya. Hasil observasi terhadap aktivitas siswa pada setiap siklus juga menunjukkan terjadinya peningkatan. Peningkatan aktivitas siswa ini terlihat dari nilai rata-rata skor observasi siswa disetiap siklusnya. Dimana pada siklus I nilai rata-rata skor siswa adalah 22,5; pada siklus II sebesar 25; dan pada siklus III sebesar 27. Sementara itu untuk hasil aktivitas siswa peraspek dapat dijelaskan seperti berikut, pada tahap stimulasi aktivitas belajar siswa yang diamati adalah listening activities. Kemudian pada tahap mengumpulkan data aktivitas yang diamati adalah motor activities. Pada awal pembelajaran hanya beberapa siswa tertentu saja yang aktif berdiskusi dan bekerja sama sedangkan siswa yang lain asyik dengan kegiatannya sendiri, untukitu guru membimbing dan mengarahkan siswa dalam menyelesaikan permasalahan yang tidak dimengerti siswa sehingga siswa lebih mudah memahami konsep pelajaran yang diberikan. Selanjutnya pada tahap memproses data aktivitas yang diamati adalah writing activities. Berdasarkan hasil kegiatan yang telah mereka lakukan skor untuk aktivitas ini selalu stabil karena pada tahap ini siswa melakukan kegiatan yang polanya hampirsama, yaitu membuat jawaban berdasarkan hasil yang mereka dapat saat mengumpulkan data sehingga siswa menjadi terbiasa. Pada tahap memverifikasi dan membuat kesimpulan aktivitas yang diamati adalah oral activities. Skor untuk kedua aktivitas tersebut selalu mengalami peninkatan pada setiap siklusnya, hal ini disebabkan karena untuk awal pertemuan siswa masih kaku saat berdiskusi dan mengeluarkan pendapat sehingga altivitas ini diawal pertemuan belum mencapai hasil maksimal, namun untuk pertemuan selanjutnya guru meminta semua kelompok untuk menanggapi dan mengeluarkan pendapat sehingga siswa mulai terbiasa dengan berdiskusi dan kegiatan diskusi menjadi lebih baik.Selain terjadi peningkatan aktivitas guru dan siswa, penerapan model pembelajaran $D L$ menggunakan media video ini juga dapat meningkatkan hasil belajar siswa. Berdasarkan data hasil belajar siswa dipeoleh peningkatan di setiap siklusnya, baik nilai rata-rata, persentase daya serap maupun persentase ketuntasan belajar klasikal siswa. Untuk siklus I diperoleh nilai ratarata siswa sebesar 69,33 dengan persentase daya serap sebesar $86,67 \%$ dan persentase ketuntasan belajar klasikal siswa sebesar $66,67 \%$. Hasil belajar klasikal yang diperoleh pada siklus I ini belum maksimal karena belum mencapai ketuntasan. Dimana, kriteria ketuntasannya adalah jika jumlah siswa yang memperoleh nilai $\geq 75$ sebanyak $85 \%$.

Adapun beberapa penyebab kurang maksimalnya hasil belajar klasikal siswa pada siklus I dengan menerapkan model pembelajaran Discovery Learning $(D L)$ menggunakan media video adalah : (1) Penerapan model pembelajaran Discovery Learning (DL) menggunakan media video pada proses pembelajaran adalah hal baru bagi siswa sehingga siswa belum terbiasa karena terbiasa dengan metode ceramah, (2) Dalam berdiskusi masih banyak siswa yang tidak ikut berpartisipasi dan hanya didominasi oleh siswa tertentusaja sehingga kondisi kelas tidak kondusif, dan (3) Saat menyelesaikan soal tes yang diberikan oleh guru masih banyak siswa yang tidak bisa menyelesaikan tepat waktu sehingga soal tes yang diberikan tidak dapat diselesaikan.

Siklus II merupakan perbaikan dari siklus I, karena setelah mengetahui kekurangan yang ada pada siklus I akan diperbaiki pada siklus II agar dapat meningkatkan hasil belajar klasikal siswa. Pada siklus II didapatkan peningkatan nilai ratarata siswa sebesar 71,33 , persentase daya serap sebesar 89,17\%, dan persentase ketuntasan belajar klasikal siswa sebesar 73,33\%. Meskipun hasil belajar yang didapatkan pada siklus II sudah mengalami peningkatan namun hasil belajar klasikal siswa masih belum memenuhi kriteria ketuntasan. Hal ini dikarenakan siswa sudah mulai terbiasa belajar dengan menerapkan model pembelajaran $D L$ menggunakan media video tapi belum sepenuhnya setiap siswa aktif untuk ikut berpartisipasi dalam diskusi kelompoknya karena masih terdapat beberapa siswa yang melakukan kegiatan lain. Selain itu, hampir semua siswa juga dapat menyelesaikan soal tes tepat waktu meskipun masih ada beberapa siswa yang belum bisa menyelesaikannya tepat waktu sehingga hasilnya belum maksimal. Pada siklus III setelah guru melakukan perbaikan dari kekurangan yang terjadi pada siklus sebelumnya, maka didapatkan hasil yang maksimal. Dimana nilai rata-rata, persentase daya serap, dan ketuntasan belajar klasikal siswa sudah memenuhi kriteria ketuntasan. Untuk nilai rata-rata pada siklus III mengalami peningkatan menjadi 81,33 sedangkan pada daya serap sebesar 
90,37\% dan ketuntasan belajar klasikal siswa sebesar $86,67 \%$. Peningkatan ini sesuai dengan kriteria ketuntasan belajar klasikal yaitu jumlah siswa yang mendapatkan nilai $\geq 75$ sebanyak $85 \%$. Sementara untuk daya serap juga sudah maksimal karena daya serap pada siklus III lebih baik dari siklus II dan daya serap siklus II lebih baik dari siklus I.

Dengan demikian dapat dikatakan secara keseluruhan melalui model pembelajaran Discovery Learning $(D L)$ meng gunakan media video peran guru hanya sebagai fasilitator bukan bersifat teacher centered (berpusat pada guru) dan siswalah yang berperan aktif dalam menemukan dan mencari sendiri sesuatu yang dibutuhkan dalam proses pembelajaran. Sehingga siswa tidak lagi menganggap pelajaran kimia sebagai pelajaran yang membosankan melainkan pelajaran yang menyenangkan. Dari hasil penelitian yang telah dilakukan pada setiap siklusnya ketuntasan belajar tercapai pada siklus III. Selain itu, persentase daya serap klasikal juga mengalami peningkatan. Sehingga dapat disimpulkan bahwa penerapan model pembelajaran Discovery Learning menggunakan media video dapat meningkatkan aktivitas dah hasil belajar siswa kelas XI IPA 1 SMA N 1 Kota Bengkulu.

\section{KESIMPULAN}

Berdasarkan hasil dari analisis penelitian yang dilakukan, maka dapat ditarik kesimpulan sebagai berikut :

Penerapan model pembelajaran Discovery Learning $(D L)$ dengan menggunakan media video di kelas XI IPA 1 SMA N 1 Kota Bengkulu mampu meningkatkan aktivitas guru dilihat dari rata-rata skor pada setiap siklusnya yang mencapai kategori baik yaitu siklus I sebesar 26,5, pada siklus II sebesar 27,5 dan 33 pada siklus III.

Penerapan model pembelajaran DLdengan menggunakan media video di kelas XI IPA 1 SMA N 01 Kota Bengkulu dapat meningkatkan aktivitas belajar kimia siswa dilihat dari rata-rata skor pada setiap siklusnya yaitu pada siklus I sebesar 22,5 (cukup), pada siklus II sebesar 25 (baik), dan pada siklus III sebesar 27 (baik).

Penerapan model pembelajaran DLdengan menggunakan media video dapat meningkatkan hasil belajar kimia siswa di kelas XI IPA 1 SMA N 1 Kota Bengkulu. Hal ini dapat dilihat dari nilai rata-rata post-testpada setiap siklusnya yaitu pada siklus I sebesar 69,33; siklus II sebesar 71,33; siklus III sebesar 81,33. Untuk daya serap klasikal pada siklus I, II, dan III secara berturut-turut adalah $86,67 \% ; 89,17 ; 90,37 \%$ dengan persentase ketuntasan belajar klasikal setiap siklusnya sebesar $66,67 \%$; 73,33\%; dan $86,67 \%$.

Berdasarkan pelaksanaan penelitian dan hasil penelitian yang telah diperoleh, maka disarankan : Guru harus mampumengorganisir siswa dengan baik saat melakukan diskusi agar waktu yang digunakan lebih efisien, agar siswa mampu bekerja sama dan saling membantu sehingga tidak ada yang lebih mendominasi dalam diskusi. Penerapan model pembelajaran Discovery Learning (DL) juga dapat digunakan pada berbagai materi kimia yang lain yang memiliki. Praktikum sehingga siswa akan lebih mudah memahami materi. Selain menggunakan media video pada model pembelajaran $D L$, media Lembar Diskusi Siswa $(L D S)$ juga dapat digunakan sebagai media pendukung.

\section{DAFTAR PUSTAKA}

1. Elvinawati., Sumpono., Hermansyah Amir., Lessons Study Pada Mata Kuliah Kimia Sekolah I Sebagai Upaya Peningkatan Kualitas Pembelajaran dan Pembangunan Karakter (Character Building), Exacta, 2012:10(2):156-159.

2. Clorawati,A.R., Salastri Rohiat, Hermansyah Amir., Implementasi Kurikulum 2013 Bagi Guru Kimia di SMA Negeri Sekota Bengkulu, Alotrop, 2017:1(2): 132-135.

3. Arifin, Zainal. 2011. Konsepdan Model Pengembangan Kurikulum. Bandung : PT Remaja Rosdakarya. ISBN 978 - 979 $692-047-1$

4. Winda , N, Implementasi Kurikulum 2013 Dalam Pembelajaran Bahasa Indonesia Berbasis Teknologi Informasi Dan Komunikasi, Stilistika: Jurnal Bahasa, Sastra, dan Pengajarannya, 2016:1(1): 87-94.

5. Buhungo, R.A., Implementasi dan Pengembangan Kurikulum 2013 Pada Madrasah Aliyah, Tadbir Jurnal Manajemen Pendidikan Islam, 2015:3(1):105-113. 
6. Nurmadiah, Kurikulum Pendidikan Islam, Jurnal Al-Afkar, 2014:3(2):41-54

7. Lestari, D.A., Pendekatan Saintifik Dalam Pembelajaran Tematik Untuk Meningkatkan Ketrampilan Bertanya Siswa, Widyagogik, 2015:3 (1):66-79.

8. Wijayati, E.C., I Nyoman Sudana Degeng, Sumarmi, Kesulitan -kesulitan Dalam Implementasi Kurikulum Mata Pelajaran IPS SMP, Jurnal Pendidikan: Teori, Penelitian, dan Pengembangan, 2016 :1 (11): 2241-2247.

9. Lestari, I.A, Hermansyah Amir, Salastri Rohiat Hubungan Persepsi Siswa Kelas X MIPA Di SMA Negeri Sekota Bengkulu TahunAjaran 2016/2017 Tentang Variasi Gaya Mengajar Guru Dengan Hasil Belajar Kimia, Alotrop, 2017:1(2):113-116.

10. Waluyo, M.E., Parmin., Pengembangan Panduan Praktikum IPA Terpadu Berbasis Inkuiri Terbimbing Tema Fotosintesis Untuk Menumbuhkan Ketrampilan Kerja Ilmiah Siswa SMP, Unnes Science Education Journal, 2014:3(3): 677-684.

11. Simanjuntak, N,D,P, Salastri Rohiat, Elvinawati., Hubungan Antara Sarana LaboratoriumTerhadap Ketrampilan Proses Sains Siswa Kelas XI MIPA 5 Di SMA Negeri 3 Kota Bengkulu , Alotrop .2017:1(2):102-105.

12. Dina, A., Venissa Dian Mawarsari, Rohmat Suprapto., Implementasi Kurikulum 2013 Pada Perangkat Pembelajaran Model Discovery Learning Pendekatan Scientific Terhadap Kemampuan Komunikasi Matematis Materi Geometri SMK, JKPM, 2015:2 (1) :22-31.

13. Nahampun, J., Efek Model Discovery Learning Berbantuan Multimedia dan Kreativitas Terhadap Hasil Belajar Peserta Didik, Jurnal Pendidikan Fisika, 2014:3(2):60-68.

14. Ginting, S.M., Hermansyah Amir., Penerapan Model PembelajaranSomatis, Auditori, Visual danIntelektual (SAVI) Berbantuan Media Komputer Untuk Meningkatkan Kualitas Pembelajaran Kimia Fisik II, Exacta, 2012:10(1):98-105.

15. Wiwit., Hermansyah.Amir, Dody Dori Putra, Penerapan Model Pembelajaran Kooperatif Tipe $T G T$ dengan dan Tanpa
Media Penggunaan Media Animasi Terhadap Hasil Belajar Kimia Siswa SMA Negeri 9 Kota Bengkulu. Exacta, 2012: 10(1):71-78.

16. Uno, Hamzah B. 2014. MenjadiPeneliti PTK yang Profesional. Jakarta :Bumi Aksara. ISBN 978 - 602-217-046- 4

17. Arikunto, Suharsini., 2010, Prosedur Penelitian :Suatu Pendekatan Praktik (EdisiRevisi 2010 Cetakan 14) Jakarta : PT Rineka Cipta. ISBN 9789800000000

18. Purnomo, B.H., Metode dan Teknik Pengumpulan Data Dalam Penelitian Tindakan Kelas (Classroom Action Research), Pengembangan Pendidikan, 2011:8(1):251-256.

19. Suryawati, Yulfikar, KualitasTes dan Hasil Belajar Matematika Siswa Kelas VIII SMP Negeri 9 Banda Aceh Tahun Pelajaran 2011/2012, Jurnal Peluang, 2012:1(1):71-80.

20. Zamsir, Kualitas Tes Buatan Guru Pada Mata Pelajaran Matematika di SD Negeri Kota Kendari, Value, Jurnal Evaluasi \& Asesmen Pendidikan, 2012:1(1):49-65.

21. Amri, R.F., Triani Ratnawuri, Pengaruh Penggunaan Strategi Pembelajaran Peningkatan Kemampuan Berpikir (SPPKB) Terhadap Hasil Belajar Kewirausahaan Siswa Kelas XI Semester Genap SMK Muhammadiyah 2 Metro T.P 2015/2016, Jurnal Promosi: Jurnal Pendidikan Ekonomi UM Metro, 2016 :4 (1):46-54.

22. Suprihatin, S., Upaya Guru Dalam Meningkatkan Motivasi Belajar Siswa, Jurnal Promosi: Jurnal Pendidikan Ekonomi UM Metro, 2015:3(1):73-82

23. Hardiani, I.N., Naniek Sulistya Wardani, Pengembangan Instrumen Penilaian Sikap Sosial Pembelajaran IPS Kelas IV SD, e-jurnal Mitra Pendidikan, 2017:1 (6):615-628.

24. Hermawati, L., Sukirman, Elvia Ivada, Upaya Meningkatkan Keaktifan Belajar dan Hasil Belajar Akuntansi Dengan Strategi Pembelajaran ARIAS Terintegrasi Dengan Pembelajaran Aktif Learning Tournament Pada Siswa Kelas X AK 2 SMK N 3 Surakarta Tahun Ajaran 2013/ 2014, Jurnal Pendidikan Ekonomi (Jupe) UNS, 2013:2(3):273-283. 
25. Winarni, Slamet Santosa, Murni Ramli, Penerapan Model Discovery Learning untuk Meningkatkan Oral Activities Siswa SMA, Bioedukasi, 2016:9(2):5561.

26. Nur'aeni , R.S., Asep Kurnia Jayadinata , Ani Nur Aeni, Penerapan Model Pembelajaran Discovery Untuk Meningkatkan Hasil Belajar Siswa Pada Materi Energi Bunyi, Jurnal Pena Ilmiah, 2017:2(1) : 611-620.
Penulisan Sitasi Artikel ini ialah

Medianty, S.U., Amrul Bahar, Elvinawati., Penerapan Model Discovery Learning Dengan Menggunakan Media Video Untuk Meningkatkan Aktivitas Belajar dan Hasil Belajar Siswa Kelas XI IPA 1 SMAN 1 Kota Bengkulu, Alotrop, 2018:2(1):58-65. 